\title{
Uusliberalismi muuttaa naisten töitä julkisella sektorilla
}

\author{
$\underline{y}$ \\ Uusliberalismi ja uusi julkisjohtamisen käytäntö \\ valtaavat alaa julkisella sektorilla. Seurauksena on paitsi \\ muutoksia naisvaltaisen hoiva-alan ammattilaisten \\ työnkuvaan ja asemaan, myös hoivan laatuun.
}

UUSLIBERALISMI ON KAIKKIALLA maailmassa vallitseva poliittinen suuntaus, joka korostaa sitä, että markkinoiden ja yksityisten yritysten tulee ohjata politiikkaa. Vastaavasti valtion ja julkisen sektorin tehtäväksi pitäisi rajata oikeuslaitoksen, poliisin ja armeijan ylläpito. Uusi julkisjohtaminen, josta käytän englanninkielistä nimitystä New Public Management (NPM) on se hallinnon tapa, jolla uusliberalismia edistetään julkisella sektorilla.

Pohjoismaissa yleensä, ja aivan erityisesti Suomessa, naiset ovat työllistyneet julkiselle sektorille. Erityisesti hyvinvointivaltio on työllistänyt naisia. 1990-luvun laman myötä Suomessa tapahtui käänne, jonka myötä hyvinvointivaltio on muuttunut markkinavetoiseksi. Vuoden 2016 sosiaali- ja terveyspalveluuudistuksen (sote) myötä on alettu puhua sosiaali- ja terveyspalveluiden siirtämisestä yhtiöiden hoitamaksi. Toteutuessaan tämä tarkoittaa julkisten sosiaali- ja terveyspalveluiden muuttamista markkinoiden tapaan toimiviksi - mutta vain toimeenpanon osalta. Tarkoitus on edelleen rahoittaa palvelut julkisista varoista, vaikka yksityiset yritykset ja kolmannen sektorin toimijat osallistuisivat palveluiden tuottamiseen.
Tarkastelen tässä puheenvuorossani sitä, miten NPM on muuttanut sosiaalialan tehtäviä, erityisesti hoivaa. Tarkastelen aluksi julkisen sektorin ja hoivan historiaa, jonka jälkeen siirryn analysoimaan uusliberalismin ja NPM:n vaikutuksia julkisella sektorilla.

\section{0-LUVUN OPTIMISMI JA HOIVAN LÖYTYMINEN}

1980-luvulla naistutkimuksen parissa vallitsi suuri kertomus, johon kuului "vahva suomalainen nainen". Naisten tasa-arvo ja yhteiskunnallisesti vahva asema palkkatyössä ja koulutuksessa olivat hyvinvointivaltion ja laajan julkisen sektorin ansiota. Aiemmin sosiaalipolitiikassa oli kuitenkin eletty vuosikymmeniä siinä uskossa, ettei sosiaalipolitiikalla ole mitään tekemistä sukupuolen kanssa. Vasta 1980- ja 1990-luvuilla sosiaalipolitiikkaa sukupuolinäkökulmasta tutkineet naiset osoittivat, että erityisesti julkiset palvelut olivat naisille tärkeitä.

1980- ja 1990-luvuilla keskustelua sosiaalipolitiikasta ja naisista hallitsivat tutkijat, jotka ryhmittyivät Hyvinvointivaltion sukupuolijärjestelmä-hankkeen alle (Julkunen \& Rantalaiho1989). Tutkimusryhmässä, 
johon itsekin kuuluin, oli kaksikymmentäkolme tutkijaa. Tutkimusta nimitettiin sateenvarjohankkeeksi, koska mukana olleiden aiheet ja lähestymistavat vaihtelivat. Tutkimus tarkasteli sukupuoleen ja/tai valtioon, järjestöihin, ammatteihin, sosiaalipalveluihin ja sosiaalityöhön liittyviä sukupuolirakenteita. Ryhmän työtä väritti optimismi ainakin 1990-luvun puoleenväliin saakka. Uskoimme, että Suomessakin hyvinvointivaltio kehittyy muiden Pohjoismaiden tasolle ja tapaan.

Ryhmän tutkijat toivat keskusteluun hoivan, käsitteenä ja käytäntöinä. Hoivan käsite tuotiin suomen kieleen englantilaisesta care (for, of, about) ja ruotsin kielen omsorg termeistä. Hoiva pitää elämää yllä; ilman ruumiillista hoivaa lapset ja muut avuttomat eivät pysy hengissä. Se on sellaista toimintaa, mitä tapahtuu lähes kaikessa ihmisten välisessä vuorovaikutuksessa.

Sosiaalipolitiikan naistutkijat puhuivat naisystävällisestä hyvinvointivaltiosta, millä tarkoitetaan palveluvaltiota tai palvelukuntaa. Naisystävällisyys merkitsee sitä, että kunta huolehtii palveluista, jotta naiset "vapautuvat" palkkatyöhön. Mutta kunta on myös naisten merkittävä työllistäjä, kun he hoivaavat lapset ja vanhat, hoitavat sairaat ja opettavat. Työnantajina kunnat takasivat kelvolliset työolot kasvattaville ja hoivaaville naisille.

Suomessa työmarkkinat ovat erityisen vahvasti sukupuolen mukaan jakautuneet miesten ja naisten töihin, vaikka naiset ovat miehiä koulutetumpia lähes joka alueella. Hoivan sukupuolirakenne ja sukupuolinen työnjako ovat säilyneet hämmästyttävän samoina vuosikymmenten läpi, olipa kysymys perheissä, vapaaehtoisena tai työmarkkinoilla tehtävästä hoivatyöstä.

Tilastokeskuksen tutkimus Naiset ja miehet Suomessa 2014 esittää miesten ja naisten kymmenen yleisintä ammattialaa. Palkansaajanaisten yleisin ammatti on tutkimuksen mukaan hoivapalvelujen ja terveydenhuollon työntekijä. Tämä pitää sisällään alan työntekijätasoiset ammatit, kuten lähi-, perus-, lasten-, mielenterveys- ja kodinhoitajan. Naisten osuus näissä ammateissa vuonna 2012 oli 93 prosenttia (164000 naista, 13000 miestä). Miesten yleisin ammatti oli kuljetustyöntekijä, ja näistä miehiä oli 96 prosenttia (111 000 miestä, 5000 naista).

\section{0-LUVUN LAMA, UUSLIBERALISMI JA NPM}

Hyvinvointivaltion sukupuolijärjestelmä -tutkimushankkeessa toisena johtajana oli Raija Julkunen (1992; 2001), joka alkoi ensimmäisenä kirjoittaa hyvinvointivaltion suunnanmuutoksesta. Sen myötä hyvinvointivaltion kehittäminen ensin pysähtyi. Sen jälkeen seurannut kustannuksista säästäminen johti hyvinvointivaltion purkamiseen ja parhaillaan sen yksityistämiseen.

Suomessa käänne tapahtui laman myötä 1990-luvulla. Tulkitsijasta riippuen lama pakotti tai mahdollisti uusliberalismin ulottumisen hyvinvointivaltioon. Hyvinvointivaltion kannattajat korostivat ja korostavat edelleen, että suomalainen hyvinvointivaltio ei edes ennen käännettä ollut erityisen kallis. Palveluita tarjoavien ammattilaisten palkat ovat meillä kohtuullisia, myös sosiaaliturvan taso on eurooppalaista keskitasoa.

1990-luvun laman ja suunnanmuutoksen jälkeen käytiin vilkasta keskustelua hyvinvointivaltion kohtalosta. Väitettiin esimerkiksi, että muutos ei ollut olennainen, vaikka sosiaaliturvan ja palveluiden tasot laskivat, kun rakenteet ja organisaatiot pysyivät ennallaan. Ajateltiin, että siirryimme hyvinvointivaltiosta hyvinvointiyhteiskuntaan, jossa valtion ja kunnan lisäksi myös kolmas sektori ja kansalaiset yhdessä yksityisten palveluntuottajien kanssa hoitavat hyvinvoinnin.

Nyt myös vuoden 2016 sote-ratkaisua puolustetaan samalla argumentilla: uudistus säilyttää hyvinvointiyhteiskunnan, koska se tarjoaa myös kolmannelle sektorille mahdollisuuden toimia palveluiden tuottajana. Tosiasiassa kolmas sektori ei ole enää aikoihin ollut vaihtoehto yrityksille, sillä myös se toimii paljolti yritysten tavoin. 1990-luvun laman myötä yhdistykset alkoivat osallistua kuntien palveluiden korvaamiseen ja ovat siksi joutuneet tuotteistamaan ja kilpailemaan markkinatoimijoiden tavoin (Nyyssölä 2009). Toisaalta järjestöt, kunnista puhumattakaan, toimivat demokraattisemmin kuin yritykset, joiden toiminta perustuu monien yritystä koskevien tietojen salaamiseen.

Uuteen sote-ratkaisuun kuuluu, että kilpailutusta järjestävät yhtiöt, mikä tarkoittaa kaiken toiminnan muuttamista yritystoiminnaksi. Kuntien tai tulevien makkuntien toimien muuttaminen yhtiöiksi tulee muuttamaan sekä hoivan sisältöä että työntekijöiden 
asemaa. Julkinen sektori ei sen jälkeen enää ole julkinen, sitä eivät ohjaa demokraattiset päätöksentekoelimet, eivätkä lautakunnat tai järjestöjen hallitukset. Hoivan tasosta ja tekijöistä päättävät sijoittajat ja heidän valitsemansa johto.

Vaikka uusliberalismi ja NPM ovat globaaleja trendejä, lait ja asetukset muokataan Suomessa omissa organisaatioissamme. Monissakaan muissa maissa ei esimerkiksi ole samanlaista kuntarakennetta kuin Suomessa, missä suuri osa hyvinvointivaltion palveluista on hoidettu kuntien kautta. Uudistukset kantavat mukanaan myös omaa historiaamme. Kun Euroopan unionin (EU) kilpailutuslainsäädäntöä sovelletaan Suomeen, paikalliset sovellutukset poikkeavat tavasta, jolla samaa ohjetta sovelletaan Puolassa tai Italiassa.

Uusliberalismin kantavana periaatteena on, että julkista valtaa pitäisi olla mahdollisimman vähän - mieluiten vain armeija ja oikeuslaitos - ja yksityistä yritteliäisyyttä mahdollisimman paljon. Periaatteessa ja käytännössä ammattilaisten toimenkuvaa muutetaan sellaiseksi, että heillä itsellään on yhä vähemmän päätösvaltaa työn sisältöön. Päätösvallan vieminen julkisella sektorilla toimivilta poliitikoilta, työntekijöiltä ja kansalaisilta on keskeinen osa uusliberaalin ideologin pohjalla olevaa julkisen valinnan teoriaa. Sen edustajien mukaan demokratia paisuttaa hallitsemattomasti julkista sektoria. Siksi NPM kannattaa vallan keskittämistä kauas toimeenpanosta. Mitä enemmän ammattilaisilla ja kansalaisilla on päätösvaltaa, sitä enemmän ja parempia palveluita he vaativat ja siksi niiden päätösvaltaa tulee vähentää (Yliaska 2014, 95-103).

Julkisten palvelujen siirtäminen yksityiselle sektorille on tapahtunut asteittain tai kahta toimintatapaa noudattaen. Osa julkisen sektorin toimista ulkoistetaan ja yksityistetään suoraan, osa asteittain yksityisten toimintatapoja, muun muassa erilaisia tilaaja-tuottajamalleja, soveltamalla. Molemmilla toimintatavoilla on seurauksia naisten asemaan sekä työntekijöinä että asiakkaina.

\section{MITEN NPM MUUTTAA NAISTEN ASEMAA JULKISELLA SEKTORILLA?}

Kun julkista sektoria yksityistetään, tai sen yksityistämistä ennakoidaan, tärkeää osaa näyttelee pysyvän muutoksen doktriini. Luodaan kriisitietoisuutta tai shokki, kuten Naomi Klein (2008) asian ilmaisee. Vaikka Suomessa on tasa-arvolaki, joka kieltää naisten syrjimisen työhönotossa, niin muutoksissa miehet pärjäävät naisia paremmin (Eräsaari 2002, 126-159). Pysyvä muutos on jatkuvaa poikkeustilaa, suunnittelemattomuutta, shokkia, kaahausta, päivästä toiseen selviämistä. Tällaiset tilanteet eivät ole omiaan työn kehittämiselle tai pitkäaikaiselle koulutukselle. Hallituksen kaavailut uudesta sosiaali- ja terveydenhuollon rakenteesta (SOTE 2016) kuvittavat pysyvän muutoksen shokkiefektiä. Valtavia rakenteellisia muutoksia tehdään ilman ennakkosuunnitelmia ja niiden lainmukaisuuskin on kyseenalaista.

Julkinen sektori on ollut yliopistokoulutettujen naisten ylivoimainen työllistäjä, terveys-, sosiaali-, opetustoimien lisäksi muun muassa juristeina ja arkkitehteina. Julkisen sektorin uudelleenmuokkaus muuttaa koulutettujen naisten asemaa radikaalisti. Terveydenhuollossa tätä tendenssiä kuvataan sanonnalla: "White coats change into grey suits" (valkoiset takit muuttuvat harmaiksi puvuiksi). Lääkäreiden ja sairaanhoitajien sijaan terveydenhoitoon tulee ekonomisteja, juristeja, konsultteja, auditoijia ja muita ammattijohtajia. Valta myös keskittyy yhä kauemmaksi katutason työstä.

Ammattijohtajien lisääntymisellä ja asiajohtajien vähentymisellä on erilaisia muotoja eri ammattialojen ja organisaatioiden yhteydessä. Siirtymä merkitsee työn luonteen muuttumista ja uutta sukupuolisopimusta. Yliopistoilla se merkitsee humanististen, kasvatustieteellisten ja yhteiskuntatieteellisten alojen merkityksen pienenemistä, niin sanotun sivistysyliopiston kuihtumista. Vastaavasti kauppatieteiden, oikeustieteen ja hallintotieteiden osuus yliopistojen sisällä lisääntyy. Yliopistoilla juuri humanistiset tieteet ovat olleet naisten aloja, joten uusliberalismi muuttaa naisten asemaa yliopistolaitoksen sisällä tulevaisuudessa myös opiskelijoina. Naisten osuus yliopistokoulutetuista tulee vähenemään ja heidän suhteellinen asemansa heikkenemään ellei joihinkin erityistoimiin ryhdytä. Tällä hetkellä toimiin ryhtyminen ei vaikuta todennäköiseltä, kun hallitus karsii opetustakin kovalla kädellä.

Itse dogma, NPM, siirtää professionaalisen työn painopistettä hoivatyöstä hallintotyöhön (management). Mitä pidemmälle NPM menee, sitä enemmän tarvitaan NPM:ää, siis järjestelmää hoitavaa henkilö- 
kuntaa. Kaikkien julkisella sektorilla työskentelevien ammattilaisten työssä lisääntyy työn hallintaan liittyvä osuus. Tämä tarkoittaa esimerkiksi suoritteiden määrän laskemista, työajan seurantaa sekä kokouksia siitä, mitä tehdään ja kuinka tekeminen tuotteistetaan (Eräsaari 2014).

NPM:n kannattajat väittävät, että uusi julkisjohtaminen vähentää byrokratiaa, mutta tosiasiassa se on lisännyt sitä - muuallakin kuin Suomessa. NPM keskittää valtaa yhdelle ammattijohtajalle. Suuntaus näkyy esimerkiksi yliopistouudistuksessa, jossa rehtoreiden valtaa lisättiin huomattavasti. Kun valtaa keskitetään, sitä vähennetään samalla jostakin, professionaalien ja ammattityöntekijöiden lisäksi asiakkailta ja kuntalaisilta. Ilmeistä suurissa organisaatioissa on, ettei vallan keskitys yhdelle henkilölle voi onnistua, joten keskittämiseen käytetään "harmaiden pukujen joukkoa". Yliopistojen ja muun julkisen hallinnon, myös kuntien hallintohenkilöstön kohdalla tämä tarkoittaa konsulttien, auditoijien, arvioijien ja projektijohtajien lisääntymistä. Näistä "johtajan apureista" käytetään myös ilmausta arviointiteollisuus. NPM:n mukaista vallan keskitystä kutsutaan etäältä johtamiseksi. Arviointiteollisuus yhdessä tietokone- ja ohjelmistoteollisuuden kanssa on keskeisessä roolissa NPM:n muokkaamassa hallinnossa.

Julkisella sektorilla on siis tapahtumassa muutos, jossa sisään otettavat ja ulos joutuvat professionaalit kokevat yhtäältä radikaaleja tehtävien ja toimenkuvien muutoksia, sukupuolenvaihdoksen ja nuorennusleikkauksen. Julkisen sektorin töiden kilpailuttaminen lisää projektimaisuutta ja työntekijöiden turvattomuutta. Projektimaisuus tekee pitkäjänteisestä organisaatioiden kehittämisestä mahdotonta, vaikka juuri se on ollut keskeinen osa hoivaavien ammattilaisten toimenkuvassa ja opetuksessa. Muutos merkitsee muutosta ammattilaisten tulevaisuushorisontissa ja siinä, mikä osuus työllä on heidän elämässään. Hoivan katsotaan tietyssä märin olevan myös kutsumus, mutta lyhytjänteisyys vie siltä pohjan.

Richard Sennett (2007, 21-80) kirjoittaa, että muutokset julkisissa organisaatioissa tarkoittavat, että sitoutuneimmat työntekijät lähtevät ensimmäisinä eivätkä jää odottamaan lykättyä palkkiota. Sennettin korostama idea lykätystä palkkiosta on lausuttu suo- malaisessa sanonnassa "valtion leipä on pitkä mutta kapea”. Ajatus valtiosta ja kunnista luotettavina, joskin saitoina työnantajina on leimannut oman sukupolveni (ns. suurten ikäluokkien) elämää, mutta lapseni eivät voi enää niin ajatella.

Hyvinvointivaltio on demokratian suurimpia saavutuksia. Sen avulla Suomi nousi suosta eturivin kansantaloudeksi. Koulutus, terveydenhuolto ja sosiaalipalvelut ovat olleet välineitä luoda vaurautta ja tasa-arvoa sekä työtä naisille. Jos julkispalvelusta luovutaan ja kuntien nykyinen toiminta yhtiöitetään esitetyllä tavalla, siirrymme sellaiseen palvelujen maailmaan, jossa kansalaisilla ei ole paikkaa yhteisen hyvän vaalimiseen. (Anttonen 2016.)

\section{HOIVAN ETIIKKA JA NPM}

Hoivaa on sekä henkistä että ruumiillista, se on prosessi, jossa keskeistä on hoivarationaliteetti tai hoivan etiikka. Etiikassa korostuu asiakkaiden tarpeiden tyydyttäminen niin hyvin kuin nykyinen tieto sallii. Hoiva on kokonaisvaltaista ja prosessimaista, mikä tekee siitä hidasta. Se on pienten, lähes näkymättömien vihjeiden tulkintaa ja niihin vastaamista. Tarpeiden tulkinta vaatii aikaa, läsnäoloa, puhumista ja kuuntelua sekä hoivaajalta että hoivan saajalta. Hoivarationaalisuus korostaa ihmistä kokonaisuutena, henkeä ja ruumista tässä ja nyt. Hoivassa keskeinen periaate on avuttoman suojelu tai nykytermein erityisesti avuttomien priorisointi: mitä avuttomampi, sen enemmän huolenpitoa. NPM:n ideologia ja käytännöt korostavat tehokkuutta, mikä tarkoittaa tavallisesti hoivatarpeiden lukumääräistä mittaamista. Sen periaatteiden mukaan aikaa vievät tapaukset kannattaa jättää hoitamatta tai pilkkoa ne useiksi pieniksi tuotteiksi.

Tyttäreni työskentelee päiväkeskuksessa, jossa järjestetään toimintaa syvästi autistisille nuorille. Nuoret tuodaan paikalle takseilla. Eräänä päivänä nuori mies kieltäytyi nousemasta kyydistä keskuksen ovella. Häntä yritettiin houkutella, uhkailla, maanitella, vetää ja työntää, mutta mikään ei auttanut. Taksikuski hermostui, koska hänen olisi pitänyt ehtiä myös muita ihmisiä kyydittämään. Hän soitti ajojen järjestäjälle ja haukkui sekä työntekijät että nuoren miehen. Lopulta taksi pistettiin ajamaan reitti uudestaan - hi- 
taammin ja totuttua reittiä. Näin saatiin nuori mies ymmärtämään tilanne ja poistumaan autosta.

Esimerkki kertoo tuotteistamisen tiukoista aikarajoista ja niiden vaikutuksista erityistarpeita vaativien ihmisten hoivaan. Esimerkki kertoo myös järjestelmän synnyttämästä kunnioitusvajeesta: kiireiset työntekijät sortuvat kiireettömiä enemmän epäkunnioittavaan puheeseen. Hoivaavien työntekijöiden kannalta kyse on siitä, että heidän on mahdoton toimia hoivan eettisten normien mukaan. Samaan aikaan kun kehitysvammaisten ja autistien ymmärtämisessä ja opetuksessa edistytään ammatillisesti, muuttaa tuotteistaminen eettisesti kestävän - sivistyneen - hoivan mahdottomaksi. Tällainen on myös hoivaajien ammatti-identiteetin kannalta tuhoisaa.

Yksinkertaiset hoivatuotteet, joista raportoidaan digitaalisesti lomakkeen tai viivakoodin avulla, ovat helpommin kaukaa kontrolloitavissa kuin monimutkaiset hoivaketjut tai näkymätön hoiva, hellä kosketus tai valoisa hymy. NPM:n suunnittelijoiden tähtäimessä on tayloristinen autotehdas satoine vaiheineen. Vanhan ihmisen housujen alas laskemisesta ja ylös nostamisesta vessakäyntien yhteydessä laskutetaan yksikköhinta tai sopimuksessa määritellään viikottaisten käyntien määrä (Lindgren 2013,13).

Hoiva ja huolenpito muodostavat prosessin, joka on epämääräinen eikä valmis koskaan. Hoivan prosessi-idea on vastakkainen tuoteideologialle, jossa auttaminen on selvästi rajattua. Ajatus hyvästä hoivasta korostaa pieniä yksiköitä, lähellä asiakkaan arkea olevia hoidon ja opetuksen rakenteita. Nyt olemme päinvastaisessa tilanteessa. Kaiken on oltava suurta tehokkuuden ja säästämisen nimissä. Tämä suurten yksiköiden tehokkuutta korostava ideologia ohittaa sen tosiasian, että palvelut tuotetaan monimutkaisten organisaatioiden toimesta.

Hoivan etiikassa välittäminen on tärkeää, sillä se takaa asiakkaan kokonaisvaltaisen hoidon. Välittäminen tarkoittaa yhtäältä tiedollista ja tunnepohjaista kiinnostumista ja sitoutumista avustettavaan ihmiseen, toisaalta yhteydenpitoa erilaisiin verkostoihin tai hallinnon eri sektoreiden välillä, yhdessä asiakkaan kanssa tai hänen puolestaan. Välittäminen sitoutumisen merkityksessä painottaa paneutuvia ja pitkäaikaisia asiakassuhteita.
NPM taas painottaa suuria määriä, joita saadaan lyhyiden asiakassuhteiden avulla. Myös välittäminen yhteistyön merkityksessä käy vaikeaksi, koska yhteistyö määritellään usein työn ulkopuoliseksi toiminnaksi. NPM:n edellyttämät käytännöt ovat vastakkaisia hyvälle hoivalle, hoivarationaalisuudelle ja professionaalisten ryhmien, kuten lääkärien, sosiaalityöntekijöiden tai opettajienkin ammattietiikalle. Työntekijöiltä ei myöskään uudistusten yhteydessä kysytä mielipidettä muutoksista, mikä sekin on omiaan vähentämään työmotivaatiota. Hoivaajilta edellytetään lähes epäinhimillistä ruumiillista ja henkistä työpanosta samaan aikaan kun heille kerrotaan symbolisesti, etteivät he taida omaa työtään.

Mänttäri-van der Kuip (2015, 74-75) nojaa väitöskirjassaan laajaan sosiaalityöntekijöitä koskevaan kyselyaineistoon. Tuloksista piirtyvä kuva sosiaalityöntekijöiden toimesta kertoo valtavista, toisinaan lähes mahdottomista asiakasmääristä. Yli kolmasosa työntekijöistä koki joutuvansa tekemään työtä ammattieettisten ohjeiden vastaisesti, lähes 80 prosenttia katsoi, ettei voi tehdä työtä niin hyvin kuin haluaisi.

\section{HALVENNETTU TYÖ}

Anu Suoranta (2009) käyttää väitöskirjassaan ilmausta "halvennettu työ" siitä kehityksestä, mikä on tapahtunut naisten työlle uusliberalismin aikana. Hän myös painottaa sitä, että naisten työ ei suinkaan ole ollut kehitystä huonosta hyväksi ja sitten taas huonoksi. Sen sijaan siinä on ollut enemmän tai vähemmän sellaisia huonon työn piirteitä, joista naiset ovat yrittäneet päästä irti muun muassa kouluttautumalla. Itse kuitenkin katson, että uusliberalismi ja NPM ovat tuoneet mukanaan uusia tapoja huonontaa työtä.

Vallan keskitys ammattijohtajille, pitkäjänteisen kehittämisen ja koulutuksen lopettaminen, päätösvallan vähentäminen professionaalisilta ryhmiltä ja katutason työntekijöiltä sekä hallinnon ja kontrollin lisääntyminen toimeenpanossa ovat sellaisia uusliberalismin piirteitä, jotka kohdistuvat ammattihierarkian ylä- tai keskitasoihin. Ammattihierarkian toinen pää, matalapalkkaiset naisten alat, ei ole sekään säästynyt muutoksilta.

Kunnat ja valtio hoitivat 1990-luvun puoliväliin myös matalapalkkaisia tehtäviä kuten kuurausta, kök- 
säystä ja kaitsentaa. Nämä kolme "k:ta” ovat käännöksiä englannin kolmesta c:stä (cleaning, catering ja caring). Nämä k:t ovat myös hoivaa, perustavanlaatuista tarpeentyydytystä. Aikaisemmin niistä saattoi myös huolehtia yksi naistyöläinen, esimerkiksi kunnallinen kodinhoitaja. Edelleenkin yksi ihminen voisi hoitaa kaikkea, mutta tehtävät jaetaan nykyisin eri henkilöille ja tavallisesti eri organisaatioille, nämä tehtävät on ulkoistettu (Eräsaari 2010, 210-222).

Kun kolme k:ta siirretään kunnilta yksityiselle niin samalla muuttuvat töitä tekevien naisten työehdot. Polly Toynbee (2003, 55-83) on laskenut, että jos kunnalla työskennelleet naiset saivat aikoinaan 100 prosenttia palkkaa, niin nykyisin yksityiset firmat maksavat palkollisilleen noin neljäkymmentä prosenttia saamastaan korvauksesta ja kuusikymmentä prosenttia menee firmojen omistajille. Omistajat ja johtajat vastaavasti saavat enemmän kuin ennen. Kolmen k:n yksityistäminen tai ulkoistaminen on ollut heikentämässä naisten palk- koja ja muita työehtoja. Yksityistetyt naisten työt perustuvat tuntikorvaukselle. Työtahtia kiristetään ja osa työajasta jää korvaamatta. Matalapalkkaisten tehtävien ehtojen heikentäminen kasvattaa yhteiskunnallista eriarvoisuutta sukupuolten ja yhteiskuntaluokkien välillä.

Hoivaketjujen pirstominen, tuotteistaminen ja yhteistyön vähentäminen työntekijöiden kesken merkitsevät kaikki ammatillistumisen vähenemistä hoivassa. Se merkitsee myös hoivan sisältöjä koskevan tiedon ja taidon vähenemistä. Tästä seuraa sisällöllisen hoivaa, koulutusta ja sosiaalityötä koskevan koulutuksen ja opetuksen merkityksen väheneminen. Samalla koulutus lisääntyy hallinnossa kuten yritystoiminnassa, tilintarkastuksessa, projektinhallinnassa, johtamisessa, kilpailuttamisessa ja konsultoinnissa.

\section{Leena Eräsaari}

YTT, dosentti

Jyväskylän yliopisto

\section{LÄHTEET}

Anttonen, A. (2016). Miksi julkispalveluiden menestystarina halutaan hävittää Suomesta? (Verkkosymposium http://www.tasaarvovaje. fi/?p=726, sit.19.08.2016)

Eräsaari, L. (2002). Julkinen tila ja valtion yhtiöittäminen. Helsinki, Gaudeamus.

Eräsaari, L. (2010). Miksi hyvinvointivaltio on tärkeä naisille? Teoksessa T. Saresma, L-M. Rossi, L-M. \& T. Juvonen (toim.) Käsikirja sukupuoleen. Tampere: Vastapaino.

Eräsaari, L. (2014). Sosiaalityö markkinoilla. Teoksessa R. Haverinen, M. Kuronen \& T. Pösö (toim.) Sosiaalihuollon tila ja tulevaisuus. Tampere: Vastapaino.

Julkunen, R. (1992). Hyvinvointivaltio käännekohdassa. Tampere: Vastapaino.

Julkunen, R. (2001). Suunnanmuutos. 1990-luvun sosiaalipoliittinen reformi Suomessa. Tampere: Vastapaino.

Julkunen, R. \& Rantalaiho, L. (toim.) (1989). Hyvinvointivaltion sukupuolijärjestelmä. Tutkimussuunnitelma. Jyväskylän yliopisto: Yhteiskuntapolitiikan laitoksen työpapereita, no 56.

Klein, N. (2008). Tuhokapitalismin nousu. Helsinki: WSOY. Lindgren, M. (2013). Kuolema Ehtoolehdossa. Helsinki: Teos.
Mänttäri-van der Kuip, M. (2015). Work-Related WellBeing among Finnish Frontline Social Workers in an Age of Austerity. Jyväskylä Studies in Education, Psychology and Social Research 524. Jyväskylä: Jyväskylän yliopisto.

Naiset ja miehet Suomessa (2014). (http://www. stat.fi/tup/julkaisut/tiedostot/julkaisuluettelo/ yyti_namisu_201400_2014_10367_net_p2.pdf. Sit. 5.7.2016)

Nyyssölä, S (2009). Puun ja kuoren välissä. Yleishyödyllisten yhteisöjen näkemyksiä omista pärjäämismahdollisuuksistaan kilpailuympäristössä. Ammatillinen lisensiaatin tutkielma, Helsingin yliopisto. http://www.sosnet.fi/loader.aspx?id=ba8efc02-1a4d4fad-b049-a9b51dc5f6f3 Sit. 19.8.2016)

Sennett, R. (2007). Uuden kapitalismin kulttuuri. Tampere: Vastapaino.

Suoranta, A. (2009). Halvennettu työ. Pätkätyö ja sukupuoli sopimusyhteiskuntaa edeltävissä työmarkkinakäytännöissä. Tampere: Vastapaino.

Toynbee, P (2003). Hard Work. Life in Low-Pay Britain. London: Bloomsbury.

Yliaska, V. (2014). Tehokkuuden toiveuni. Uuden julkisjohtamisen historia Suomessa 1970-luvulta 1990-luvulle. Helsinki: Into. 